AUTHOR CORRECTION OPEN

\title{
Author Correction: Clinical validation of smartphone-based activity tracking in peripheral artery disease patients
}

Raheel Ata, Neil Gandhi, Hannah Rasmussen, Osama El-Gabalawy, Santiago Gutierrez, Alizeh Ahmad, Siddharth Suresh, Roshini Ravi, Kara Rothenberg (iD) and Oliver Aalami

npj Digital Medicine (2020)3:105; https://doi.org/10.1038/s41746-020-00316-0

Correction to: npj Digital Medicine https://doi.org/10.1038/s41746018-0073-x, published online 11 December 2018

The original version of the published Article had a mistake in the first two sentences of the Author contributions section. The Author contributions have been updated to the following: R.A., N.G., H.R., and O.E. should be considered as co-first authors.

The HTML and PDF versions of the Article have been corrected.

\begin{abstract}
(i) Open Access This article is licensed under a Creative Commons Attribution 4.0 International License, which permits use, sharing, adaptation, distribution and reproduction in any medium or format, as long as you give appropriate credit to the original author(s) and the source, provide a link to the Creative Commons license, and indicate if changes were made. The images or other third party material in this article are included in the article's Creative Commons license, unless indicated otherwise in a credit line to the material. If material is not included in the article's Creative Commons license and your intended use is not permitted by statutory regulation or exceeds the permitted use, you will need to obtain permission directly from the copyright holder. To view a copy of this license, visit http://creativecommons. org/licenses/by/4.0/.
\end{abstract}

This is a U.S. government work and not under copyright protection in the U.S.; foreign copyright protection may apply 2020 